\title{
The Russian-Chinese Cooperation in the Humanitarian Sphere
}

\author{
Anatoly Tsvyk \\ Faculty of Humanities and Social Sciences \\ RUDN University \\ Moscow, Russia \\ tsvyk_av@rudn.university
}

\author{
Galina Tsvyk \\ Faculty of Humanities and Social Sciences \\ RUDN University \\ Moscow, Russia \\ tsvyk_gi@rudn.university
}

\begin{abstract}
The following article highlights the key aspects of the bilateral cooperation between the Russian Federation and the People's Republic of China in the humanitarian field. The authors argue that Russia and China are interested in developing and deepening the strategic partnership in this sphere and come to the conclusion that nowadays Russia and China have a strong foundation and long-term prospects for the development of bilateral humanitarian ties.
\end{abstract}

Keywords-Russian Federation; People's Republic of China; humanitarian cooperation; culture; education; bilateral relationships; strategic partnership

\section{INTRODUCTION}

At the present stage, the Russian-Chinese cooperation has reached a new level - the level of mutually beneficial interaction of cultures keeping the special nature of both. Choosing this way of cooperation development of the two countries became the towering achievement of external policy of Moscow and Beijing at the beginning of the XXI century: cultural cooperation between the countries has become an exemplar of stability and mutual benefit. Coming together of the nations in cultural area in the 2000s passed a long way from stereotypic misunderstanding of each other's cultural environment to mutual respect of cultural heritage of the two countries by the peoples.

\section{LEGAL AND REGULATORY FRAMEWORK FOR COOPERATION}

Significant role in establishing of the Russian-Chinese cooperation was played by the Treaty of GoodNeighborliness and Friendly Cooperation between the People's Republic of China and the Russian Federation signed July 16, 2001 [1]. This document formalized the changes that had happened in both countries from the beginning of the 1990s and laid a more solid ground for cooperation of the two states. The Treaty incorporates the most important principles of the Russian-Chinese relationship, main areas of their cooperation and further prospects of the world order development. An important article of the Treaty is the article on mutual respect by the countries of their political, economic, cultural and social development (Article 3 of the Treaty). The Document also confirmed the readiness of both states to continue the more than 200 years cooperation and put on paper specific decisions in the area of two-way trade and economic and cultural relations. That was the moment when the relations between Moscow and Beijing got the name of "strategic partnership".

Contractual and legal framework for development of cultural relations between Russia and China consists of intergovernmental agreements on cultural cooperation signed December 18, 1992, intergovernmental plans for cultural cooperation, as well as road maps for cooperation between specific authorities of both countries for several years [2].

Special focus in The Joint Declarations between the Russian Federation and the People's Republic of China of 2005, 2006 and 2007 is on interaction in cultural field as an important part of intensive two-way cooperation. They read that the state policy aims towards preservation of the national cultural diversity, stress the need to strengthen the role of exchanges in the areas of education, culture, tourism and mass media to create trusting relationships not only at the top level, but also between the citizens of Russia and China.

\section{MAIN MECHANISMS OF HUMANITARIAN COOPERATION.}

From the beginning of the 2000s the cooperation of both countries in the educational field has had a diverse character. After the Treaty of Good-Neighborliness and Friendly Cooperation Between the People's Republic of China and the Russian Federation was signed, the cooperation of educational systems of the countries switched to a new mode. Confucius Institute, Rossotrudnichestvo, China-Russia Friendship Association, China and Russia Intergovernmental Committee for cooperation in the area of education, culture, science and sports, China and Russia Committee for humanitarian cooperation, Subcommittee for education of the China and Russia Committee for humanitarian cooperation are the main tools for implementation of the agreements between the two countries [3]

From the Russian side the Committee is chaired by $\mathrm{O}$. Yu. Golodets, Deputy Chairman of the Government of the Russian Federation, and from the Chinese side - by Liu Yandong, Vice Premier of the People's Republic of China. For the time of its work, the Committee reached a number of 
important records. For example, the parties decided to extend mutual exchange of students to 100 thousand people by 2020 . In 2012 the Committee signed the Memorandum on the implementation of the Action Plan for Russian-Chinese cooperation in the humanitarian sphere until 2020 [4]. It includes a variety of ways: joint preparation of specialists according to programs of higher and postgraduate education, activation of direct interuniversity relations, expansion of youth exchanges in the education sphere, particularly through conduction of Years of youth cross-exchanges (2014 - 2015), improvement of methods of teaching Russian and Chinese as foreign languages, formation of new models for cooperation of the two states. This Plan has delivered real results: by the end of 2016 around 190 Russian universities had direct relations with nearly 700 universities of the PRC, more than 1000 bilateral agreements were signed.

\section{PRIORITIES IN THE SPHERE OF HUMANITARIAN COOPERATION.}

Besides culture, a very important direction in humanitarian cooperation of Moscow and Beijing is education, mainly concerning languages study in schools and universities of the two countries.

As far back as in 1995, Russia and China mutually recognized qualifications and academic degrees to be equivalent for the educational institutions of each other, which had been formalized with the special Agreement between the Government of the Russian Federation and the Government of the People's Republic of China on Mutual Recognition of Qualifications and Academic Degrees dated June 26, 1995 [5].

Equally important event within the frame of bilateral Russian-Chinese relationships is the project for National Years: Year of Russia in China (2006) and Year of China in Russia (2007) [6]. It became the first big project in interstate relationships between Moscow and Beijing, as it covered all areas of the two states interactions from political to humanitarian. Organizational committees created for implementation of activities planned for 2006-2007 in China and Russia later initiated execution of other great projects.

During National Years a lot of activities with cultural themes, in educational sphere and exchange of school and university students etc. were carried, as well as a number of exhibitions. Events that took place during Year of Russia in China and Year of China in Russia particularly can be named a turning point in bilateral interaction of the two countries: after implementation of this project both states continued to hold similar events.

Confucius Institutes play an important role in development of Russian-Chinese humanitarian cooperation and have become one of the main tools for spread of the Chinese language across Russia. In 2006-2007 Confucius Institutes were open on the base of such universities as Russian State University for the Humanities, Saint Petersburg State University, Moscow State University named after M.V. Lomonosov etc. As of today, there are 20 Confucius Institutes across Russia and over 600 in the world [7]. Chinese Pushkin society, Association for study of the
Russian and Soviet literature and Centers of the Russian language opened in Beijing and other big cities in China are actively involved into promotion of the Russian language in China [8].

\section{CHALLENGES AND OPPORTUNITIES}

Long-term prospects for humanitarian cooperation between Russia and China can be estimated as positively and rapidly advancing. This is first linked with mutual interest of the both countries for development of this area. Secondly, with close cooperation between Moscow and Beijing on the international stage in political, economic, energy and other areas, considering the current situation in the international relations [9]. Thirdly, based on the statistics for education of the Chinese citizens, an upward trend for yearly increase of Chinese students and teachers willing to come to Russia can be seen.

Certainly, in the bilateral humanitarian cooperation problems exist in the cultural sphere, particularly related to insufficient legal base, that directly affects the cultural cooperation of the two countries.

Another problem in the cultural cooperation remains lack of places in Russia for promotion of the Russian language. Today a lot of school and university students from China are eager to study Russian, particularly in the Russian Federation, which highlights the importance of joint work of the parties in this direction.

Yet another issue is shortfall in teachers of the Russian language. This problem is closely related to the above mentioned one, as there is lack of highly-qualified personnel for teaching of the Russian language in the Chinese universities and schools.

\section{CONCLUSION}

Summarizing the above, it is necessary to note the importance of humanitarian cooperation development between Russia and China. Historically formed close cooperation between the two countries cannot be broken even by the current situation on the international stage. Governments of both countries have envisioned a long-term continuation and strengthening of cooperation in the cultural, educational, touristic, sports etc. spheres.

\section{REFERENCES}

[1] Website of the Ministry of the Foreign Affairs of the Russian Federation. List of bilateral international treaties of the Russian Federation. Available at: http://www.mid.ru/bdomp/spd_md.nsf/0/A1AE8363F456CBC643257 E270042E32.

[2] The Agreement between the Government of the Russian Federation and the Government of the People's Republic of China on cultural cooperation (Signed in Beijing, 18.12.1992). Available at: https://www.lawmix.ru/abrolaw/13128.

[3] 29.10.1957 in Moscow was held the founding meeting for the creation of the Soviet-Chinese Friendship Association. Website of the Institute of Far Eastern Studies (IFES). Available at: http://orkd.ifesras.ru. 
[4] The Russian-Chinese intergovernmental negotiations. 6.12. 2012. Website of the Russian Government. Available at: http://archive.government.ru/special/docs/21776/.

[5] The Federal Center of educational legislation. The Agreement between the Government of the Russian Federation and the Government of the People's Republic of China "On mutual recognition and equivalence of education documents and academic degrees". (Signed 26.06.1995). Available at: http://www.lexed.ru/search/detail.php?ELEMENT_ID=3885.

[6] Vladimir Putin signed the order about carrying out of the Year of Russia in China in 2006 and Year of China in Russia in 2007. Website of the President of the Russian Federation. Available at: http://www.kremlin.ru/events/president/news/33638.

[7] Liu Yandong. Collaboration for the sustainable development of Confucius Institutes: the keynote speech at the V Congress of Confucius Institutes. The Confucius Institute (the Russian-Chinese version). Number 1 (Jan.), 2011, p. 10.

[8] G. Ganshina, A. Tsvyk, Promotion of Russian Language in China As a Tool of Cultural Diplomacy of the Russian Federation, ICADCE 2016, "Advances in Social Sciences, Education and Humanities Research”, 2016, Atlantis Press, pp. 1285-1289.

[9] Tsvyk A.V. "The Evolution of the Conceptual Basis of the Foreign Policy of the PRC (1950-1990)", RUDN Bulletin, International Relations, 2015, Volume 15, Number 1, pp. 53-59. 